\title{
11 Legitimacy and Modes of Global Governance
}

\author{
Fonas Tallberg
}

The architecture of global governance has undergone profound changes in recent decades. On the one hand, states have continued to empower the hierarchical international organizations (IOs) that were established in the post-Second World War era and constitute the backbone of global governance. ${ }^{1}$ While IOs no longer constitute the growth area in global governance, those that exist have been conferred ever more authority in an increasing range of policy domains. On the other hand, we have witnessed a proliferation of new modes of global governance, involving a shift toward network- and market-based organization. ${ }^{2}$ Transgovernmental networks (TGNs), transnational hybrid institutions (THIs), and transnational private arrangements (TPAs) have emerged in a broad range of policy areas. ${ }^{3}$ As a result, various forms of non-state actors have assumed a more prominent role in the governing of global concerns. ${ }^{4}$ This chapter follows on from previous chapters in this volume that have documented this transformation in the architecture of global governance. Instead of offering further testimony of this trend, it explores one of its potential sources: the legitimacy of old and new forms of global governance. Specifically, it examines whether the gradual shift from hierarchical IOs and toward TGNs, THIs, and TPAs could be explained by a decline in the legitimacy for old-style governance and the promise of higher legitimacy for new-style governance. Legitimacy is understood here as the perception or belief within a given audience that an

\footnotetext{
Deborah Avant, Michael Barnett, Lisa Dellmuth, Kal Raustiala, Jon C.W. Pevehouse, Jan Aart Scholte, and Soetkin Verhaegen have all provided very helpful comments on earlier drafts of this chapter. In addition, I am indebted to Karin Sundström and Soetkin Verhaegen for invaluable assistance with public and elite survey data. Finally, I would like to thank Riksbankens Jubileumsfond (Grant M15-0048:1) for generous financial support.

${ }^{1}$ Hooghe et al. 2017; Zürn 2018.

2 Slaughter 2005; Kahler 2009; Avant et al. 2010; Weiss and Wilkinson 2014; Kelley and Simmons 2015; Introduction.

3 As documented in Chapters 3, 6, and 10, for instance.

4 Tallberg et al. 2014; Andonova 2019.
} 
institution's authority is appropriately exercised. ${ }^{5}$ Legitimacy in this sociological sense is an attribute of an institution, based on audience beliefs, and may vary over time and across audiences. This chapter examines the perceived legitimacy of old and new modes of governance among both publics and elites, mapping their degrees of confidence in global institutions across time and space.

The chapter suggests that legitimacy concerns are of limited importance in explaining the shift toward newer modes of global governance. It arrives at this conclusion in three steps. First, it shows how legitimacy concerns feature as a causal mechanism in prominent accounts of the transformation of global governance. Explanations highlighting geopolitical shifts, changing governance norms, and domestic backlash to globalization all suggest that concerns with the legitimacy of liberal hierarchical IOs help to drive the development toward alternative forms of governance. Second, it draws on public and elite opinion data to assess empirically (1) whether the perceived legitimacy of traditional IOs is in decline and (2) whether new-style governance is considered more legitimate than old-style governance. It finds mixed support for the first expectation and no support for the second. Third, it discusses potential reasons why the legitimacy of traditional IOs appears to hold up well in comparison to TGNs, THIs, and TPAs. Specifically, it highlights institutional reforms to IOs that may have helped to defuse legitimacy concerns, the limitations of new-style institutions in meeting societal standards of appropriate governance, and the role of heuristics in the formation of legitimacy beliefs among citizens and elites.

\section{Why Legitimacy Might Drive New Modes of Governance}

In the Introduction to this volume, Barnett, Pevehouse, and Raustiala identify potential sources of the shift toward new modes of global governance. A decline in the legitimacy of traditional hierarchical IOs does not feature explicitly among these structural drivers. Yet legitimacy concerns are arguably an integral part of why some of these factors would propel a shift toward network- and market-based global governance. In this section, I suggest that arguments emphasizing geopolitical shifts, changing governance norms, and domestic backlash to globalization rely

${ }^{5}$ E.g., Weber 1978 [1922]; Suchman 1995; Hurd 2007; Tallberg et al. 2018; Tallberg and Zürn 2019. This sociological conception of legitimacy is different from a normative understanding, where an institution's legitimacy is derived from its conformance to philosophical values such as justice and democracy (Buchanan and Keohane 2006). 
partly on legitimacy as a causal mechanism, linking structural change and governance transformation.

\section{Geopolitical Shifts}

Existing scholarship on geopolitical shifts and global governance frequently accords legitimacy considerations an important theoretical role. ${ }^{6}$ According to the conventional story, the USA and its allies successfully constructed a liberal international order in the aftermath of the Second World War. The core of this liberal order comprised a number of hierarchically organized IOs, among them the International Monetary Fund (IMF), the World Bank, the General Agreement on Tariffs and Trade (GATT), and the United Nations (UN). These IOs were structured to favor the interests of the Western powers both in terms of procedural rules and substantive policies. Procedurally they institutionalized inequalities by giving the Western powers particular advantages in decision-making. The IMF and the World Bank distributed voting power based on capital contributions, the UN granted exclusive veto power to five great powers, and the GATT informally relied on agreements between the USA and Europe. Substantively these IOs tended to pursue policy agendas aligned with Western liberal ideals of free trade, human rights, and liberalization. This liberal international order reached its climax in the 1990s, when the Western powers, inspired by the end of the Cold War, moved to expand the North Atlantic Treaty Organization (NATO) and the European Union (EU), create the International Criminal Court (ICC), and introduce norms such as responsibility to protect, human security, and sustainable development.

With the ascent of the rising powers the legitimacy of this international order has been called into question. What may have appeared as a legitimate system in times of Western dominance is increasingly seen as biased, unjust, and unreflective of economic and political realities. The distribution of capabilities has fundamentally shifted in favor of the rising powers, while the USA and its allies are in relative decline, economically, demographically, and militarily. This shift in geopolitical weight has gone hand in hand with demands for greater representation, influence, and recognition in global governance. At the forefront of these demands are the BRICS - Brazil, Russia, India, China, and South Africa - but other regional powers also call for greater voice.

${ }^{6}$ Morse and Keohane 2014; Ikenberry 2018; Zürn 2018; Stephen and Zürn 2019. 
According to this account the challenges to the prevailing order are intimately bound up with the question of legitimacy. "[T] he crisis of the liberal order is a crisis of legitimacy and social purpose," argues Ikenberry. ${ }^{7}$ Similarly, Stephen submits that: "The legitimacy of the rules and leadership roles of global governance is in dispute." ${ }^{8}$ Contributions typically highlight how the existing order is criticized as illegitimate, leading to demands for fairer representation on governing bodies. For instance, regional powers without permanent seats call for institutional reforms that would make the UN Security Council (UNSC) more legitimate. China demands a recalibration of the system of voting weights in the IMF and the World Bank. Brazil and India request to become part of the core negotiating group of the World Trade Organization (WTO), previously restricted to the USA, the EU, Japan, and Canada. According to one interpretation these demands in themselves reflect the declining perceived legitimacy for the hierarchical IOs at the core of the liberal international order. ${ }^{9}$ When criticizing these IOs the emerging powers demonstrate their lack of faith in the current system of governance. According to another interpretation these challenges rather amount to deliberate efforts at delegitimation, designed to put moral pressure on the current power holders of these IOs for purposes of achieving a rebalancing of privileges. ${ }^{10}$

On this view the geopolitical shift, through its effects on legitimacy, has produced a number of consequences for the architecture of global governance. When the incumbent powers heed demands for more equitable representation the result is institutional reforms to existing hierarchical IOs. ${ }^{11}$ Such reforms are often interpreted as attempts at relegitimation intended to shore up support for an organization. ${ }^{12}$ Examples include the rebalancing of voting weights in the IMF and the marginal reforms to the UNSC. Other adaptations to the geopolitical shift entail a step away from the traditional IOs of the post-Second World War era and toward greater complexity in global governance. One of the most significant trends is the growing informalization of cooperation, both in terms of country groupings and negotiated agreements. ${ }^{13}$ For instance, the G7 has been supplemented by the G20 to accommodate demands from regional powers for representation on this informal TGN. Moreover, rising powers are forming informal clubs of their own, including the BRICS Forum, the IBSA (India, Brazil, South Africa) Dialogue Forum, and the BASIC

${ }^{7}$ Ikenberry 2018, $19 . \quad{ }^{8}$ Stephen 2017, 483.

${ }^{9}$ Ikenberry 2018; Stephen and Zürn 2019.

10 Binder and Heupel 2015; Kruck and Zangl 2020. $\quad{ }^{11}$ Zangl et al. 2016; Lipscy 2017.

12 Zürn 2018; Tallberg and Zürn $2019 .{ }_{13}$ Vabulas and Snidal 2013; Stephen 2017. 
(Brazil, South Africa, India, China) bloc. The effect is a layering of global governance, where new-style network institutions coexist and sometimes build upon old-style hierarchical IOs. ${ }^{14}$

\section{Changing Governance Norms}

A second structural argument granting legitimacy a causal role highlights historical shifts in governance norms. According to this argument the dominant ideologies of governance have undergone important change in recent decades, altering the standards of what is perceived as legitimate forms of global governance. This shift in governance norms has put pressure on traditional hierarchical IOs, which have sought to adapt to this new normative landscape through institutional reforms, and stimulated new modes of global governance, constitutively more in line with the new standards of appropriateness.

On this view the traditional hierarchical IOs were established in a period when the prevailing governance norm prescribed pursuit of collective welfare through state-based cooperation. Consistent with this norm, IOs were organized as forums for intergovernmental negotiation, assisted by Weberian international bureaucracies, and infused with ambitions of technocratic problem-solving. ${ }^{15}$ The legitimacy of IOs in this period was best described as output-based, resting on these organizations' capacity to produce collective benefits for states and societies. ${ }^{16}$ With the end of the Cold War the dominant governance norm began to change. The combination of two factors helped to drive this development: the third wave of democratization and the growing authority of IOs. The effect was a shift in the societal norms used to evaluate the legitimacy of global governance, away from technocratic performance and toward democratic procedure.

On the one hand, the third wave of democratization helped to elevate democratic standards as governance norms. The end of the Cold War brought widespread democratization of former authoritarian states in Central and Eastern Europe as well as other areas of the world. ${ }^{17}$ Illustrating the general burst of optimism about liberal democracy at the time, Fukuyama famously spoke of "the universalization of Western liberal democracy as the final form of human governance." 18 This upgrading of democratic norms at the domestic level had knock-on

${ }^{14}$ Stephen 2017; Zürn 2018, chapter 7.

15 Barnett and Finnemore 2004; Rittberger et al. 2012.

16 Scharpf 1999; Buchanan and Keohane 2006. ${ }^{17}$ Gleditsch and Ward 2008.

18 Fukuyama 1992, 3. 
consequences for the standards used to evaluate the appropriateness of global governance. While democratic standards of participation, accountability, and transparency historically had taken a back seat in the justification of IO policy-making, such concerns now gained in importance as liberal states sought to extend abroad the ideals to which they adhered domestically. ${ }^{19}$ Some even suggest that democracy became the new gold standard of global governance. ${ }^{20}$

On the other hand, the growth in IO authority challenged the conventional understanding of these organizations as intergovernmental negotiation machineries, consistent with state consent, national sovereignty, and domestic democratic control. In a dual move away from the intergovernmental ideal type, supranational bodies within IOs had been delegated ever more authority, while interstate decision-making increasingly took place through procedures that pooled authority at the expense of national autonomy. ${ }^{21}$ The quintessential example was the EU, but the trend extended well into the broader population of hierarchical IOs. Yet, as IOs gained greater authority at the expense of national governments, producing collective benefits gradually came to be seen as an insufficient basis for the legitimacy of these organizations. Instead, being perceived to satisfy democratic criteria of decision-making was regarded as increasingly central for IOs. ${ }^{22}$ While the term "democratic deficit" hardly existed in the 1980s, it became a prominent way of characterizing and criticizing traditional IOs from the 1990s onwards. ${ }^{23}$

In this perspective, the shift from technocratic performance to democratic procedure as a governance norm helps to explain recent changes in the nature of global governance. Recognizing the shift in societal norms, actors have sought to move toward institutional designs that allow them to claim legitimacy. On the one hand, hierarchical IOs have engaged in institutional reforms that introduce stronger elements of democratic procedure. A growing number of IOs have established international parliamentary institutions, opened up policy-making to civil society actors, strengthened accountability mechanisms, and introduced transparency policies. ${ }^{24}$ While strongest in IOs dominated by democracies, these trends extend to organizations whose memberships are authoritarian, pointing to the strong impact of externally legitimated models.

19 Risse-Kappen 1996; Moravcsik 1997; Tallberg et al. 2016.

20 Held 1995; Bodansky 1999. ${ }^{21}$ Hooghe et al. 2017; Zürn 2018.

22 Scharpf 1999.

23 Dahl 1999; O’Brien et al. 2000; Zürn 2000; Norris 2011; Binder and Heupel 2015; Dingwerth et al. 2019.

${ }^{24}$ Grigorescu 2007, 2010; Tallberg et al. 2013, 2014; Rittberger and Schroeder 2016; Rocabert et al. 2019. 
On the other hand, state and non-state actors have negotiated new forms of global governance that aim to be more participatory by construction. Notably, multi-stakeholder partnerships have emerged as an alternative model, often seen to hold the promise of greater legitimacy (and effectiveness) due to its network construction, involving both state and non-state actors. ${ }^{25}$ These new modes aim to meet democratic governance norms, not through old-style state representation but through stakeholder engagement and non-electoral forms of accountability.

\section{Domestic Backlash to Globalization}

A third structural argument in which legitimacy features prominently as a causal mechanism is that of a domestic backlash to globalization. According to this argument globalization has brought about new economic and political cleavages at the domestic level, which anti-globalist political entrepreneurs have exploited to breed discontent with existing global governance arrangements. ${ }^{26}$ The most prominent expression of this backlash is the recent populist surge in Europe, the USA, and elsewhere, involving a rejection of IOs as expressions of a global faceless elite. Another example is the backlash in many countries against international courts, increasingly seen to interfere with national sovereignty. ${ }^{27}$ In this explanation legitimacy concerns are at the core of the shift toward alternative forms of governance, or away from global cooperation altogether.

The deeper roots of the domestic backlash are usually sought in globalization's consequences for economic distribution and cultural values. ${ }^{28}$ On the one hand, economic globalization and specialization have fundamentally transformed societies, leaving some segments more economically insecure even when benefiting countries as a whole. On the other hand, societal transformations that brought about a cultural shift among the younger and more educated toward post-materialist values, such as environmental protection, gender equality, and multiculturalism, clashed with more traditional values in older and less educated groups. To these economic and cultural processes, commonly emphasized in work on populism, should be added the expanding authority of IOs themselves, whose policies increasingly reach behind borders and impact core areas of state sovereignty. ${ }^{29}$

25 Benner et al. 2004; Bäckstrand 2008; Andonova 2019.

27 Alter et al. 2016; Voeten 2020. 28 Inglehart and Norris 2017.

29 Hooghe et al. 2017; Zürn 2018. 
According to this narrative IOs have long profited from a state of "permissive consensus," in which populations enjoyed the fruits of cooperation and supported its broad goals but took little interest in the process as such. ${ }^{30}$ With the impact of globalization and the rising power of IOs this consensus has given way to a state of "constraining dissensus," in which international issues are divisive and the legitimacy of cooperation itself is increasingly called into question. ${ }^{31}$ Global governance is no longer a distant process of generally positive outcomes but a subject of domestic partisan contestation. As Hooghe et al. put it, global governance is now embedded in partisan conflict: "Counter-movements of leftists and nationalists have been at the forefront in challenging the legitimacy of IOs. Opposition began on the left, though in most recent years it has been strongest among nationalists who frame their opposition to international governance as defense of the nation against transnational influences, above all immigrants." 32

In this new setting IOs are targeted by populists as proxy representatives of an otherwise faceless process of economic and cultural globalization, but also as contributors to these processes through the impact of their policies. The examples of populist leaders on the right and the left who pursue agendas of anti-globalism are manifold. Then US President Donald Trump challenged the authority of the WTO, took the USA out of the Paris Agreement on climate change, questioned transatlantic security cooperation within NATO, and vowed to take the USA out of the World Health Organization (WHO). Marine Le Pen, leader of the French far-right party Rassemblement National, declared globalization her enemy number one in the presidential election of $2017 .{ }^{33}$ Michael Gove, then justice secretary and leading advocate for Brexit, criticized the EU for being "distant, unaccountable, and elitist," before famously adding that "this country has had enough of experts from organizations with acronyms." ${ }^{34}$ Rodrigo Duterte, president of the Philippines, has countered international criticism by claiming the UN to be worthless and by threatening to pull the country out of the organization. ${ }^{35}$ Attacking IOs from the left, Yanis Varoufakis as Greek finance minister submitted: "What [the EU and IMF] are doing with Greece has a name: terrorism." 36

On this perspective the populist challenge has already contributed to changing the nature of global governance. The consequences are particularly negative for the traditional hierarchical IOs, whose political

30 Lindberg and Scheingold 1970. $\quad 31$ Hooghe and Marks 2009.

32 Hooghe et al. 2019. ${ }_{33}$ Politico, February 5, 2017. ${ }^{34}$ Sky News, June 3, 2016.

35 BBC, August 21, 2016. 36 The Guardian, July 7, 2015. 
authority and contributions to transnational exchange have made them especially unpopular. Several IOs face withdrawals or threats thereof, including the EU, the ICC, the UN Human Rights Council, the United Framework Convention on Climate Change (UNFCCC), and WHO. Other IOs become subject to renegotiation of foundational rules, such as the North American Free Trade Agreement, or efforts at undermining their authority, such as the WTO. The beneficiaries of this trend remain to be identified but could potentially include more market- or networkbased forms of global governance. The strategies of the Trump administration and the British government following Brexit appeared to strengthen an already ongoing development toward a bilateralization of global governance. ${ }^{37}$ Likewise, the growing prominence of market-based ratings and rankings, also as governance tools of conventional IOs, could reflect an effort to move toward governance forms perceived as less intrusive and more legitimate. ${ }^{38}$

\section{Legitimacy in Global Governance: The Empirical Record}

In the previous section I suggested that legitimacy concerns feature as a causal mechanism in some of the most prominent efforts at explaining the shift toward new modes of global governance. Geopolitical shifts, new governance norms, and domestic backlash to globalization are structural changes whose consequences for global governance are partly expected to work through their effects on legitimacy. In this section I discuss these expectations in light of the empirical record. In focus are two observable implications. First, we would expect to observe a steady decline in the legitimacy of traditional hierarchical IOs over time, as these structural changes challenge the perceived appropriateness of these organizations. Second, we would expect to see new forms of global governance being awarded greater legitimacy than old conventional IOs, since they partly grow out of efforts to meet these legitimacy challenges. The empirical answer is tentative, as data limitations restrict the scope of comparisons over time and across institutions. Yet the available evidence suggests a picture that is partly different than the one expected. While there are some indications that traditional hierarchical IOs have witnessed declining legitimacy over time, those are not conclusive. In addition, traditional hierarchical IOs appear to enjoy more legitimacy on average than new modes of global governance.

37 Baccini and Dür 2014. $\quad 38$ Kelley and Simmons 2015. 
In line with a growing body of research in comparative politics and international relations, I rely on survey data and people's confidence or trust in institutions as a way of capturing legitimacy beliefs. ${ }^{39}$ This operationalization is anchored in systems theory, which conceives of legitimacy as the reservoir of confidence in a political system, independent of short-term satisfaction with its distributional outcomes. ${ }^{40}$ Different from some alternative operationalizations of legitimacy, it has the advantage of not integrating into the measure (1) potential sources of legitimacy, such as fairness or effectiveness or (2) potential consequences of legitimacy, such as compliance or protest. For data I consult established large-scale surveys of public opinion, but also a new and unique survey of elite opinion on global governance. The combination of public and elite opinion data helps to capture legitimacy beliefs among the multiple audiences of global governance.

\section{Declining Legitimacy for Traditional IOs?}

To begin with I explore over-time patterns in the perceived legitimacy of traditional hierarchical IOs. Unfortunately survey data exist only for a limited number of IOs, and then often in a non-comparable format, which helps to explain the dearth of systematic comparative research on the legitimacy of global governance institutions. ${ }^{41}$ The World Values Survey (WVS) measures public opinion toward a number of IOs, but the organizations covered vary across survey waves, as do the countries included. Regional surveys, such as the Eurobarometer, Latinobarometer, and Afrobarometer, typically only cover attitudes toward a specific regional IO. I therefore choose to focus on the two IOs for which we have the most extensive and complete time-series - the UN and the EU. While these two IOs cannot be taken to represent the full population of organizations, they are probably the most prominent IOs in global and regional governance, respectively. In addition, they are among the traditional IOs enjoying the highest level of authority and most often claimed to suffer from legitimacy deficits. ${ }^{42}$ If the legitimacy of hierarchical IOs is in steady decline, this is where we would expect to see it.

Starting with the UN, Figure 11.1 shows the extent to which citizens have had a great deal or quite a lot of confidence in this IO over the time

39 E.g., Newton and Norris 2001; Inglehart and Welzel 2005; Johnson 2011; Voeten 2013; Dellmuth and Tallberg 2015.

40 Easton 1975, 447. $\quad{ }_{41}$ Dellmuth 2018.

42 Hurd 2007; Binder and Heupel 2015; Scharpf 1999; Lord and Beetham 2001. 


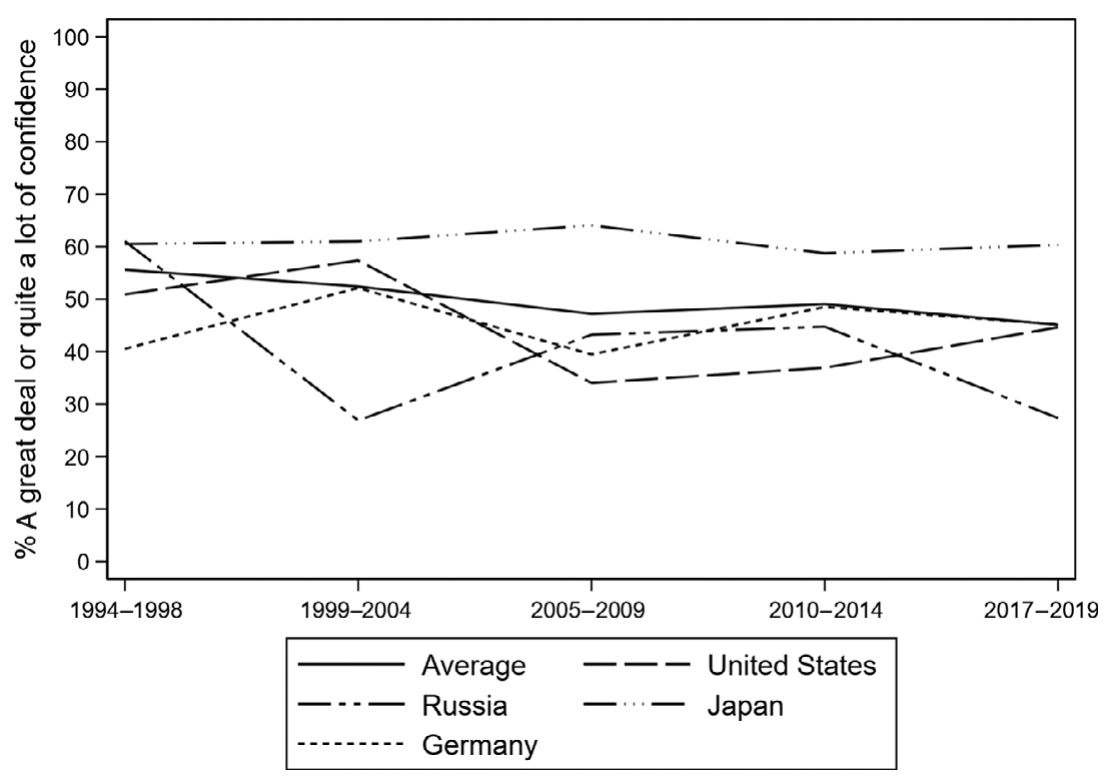

Figure 11.1 Confidence in the UN, 1994-2019.

Note: Author's presentation based on data from WVS waves 3-7. Countries included in the calculation of the average confidence in the UN are those in which the question was asked in all five waves: Argentina, Belarus, Chile, Estonia, Germany, Japan, Mexico, Peru, Poland, Romania, Russia, Slovenia, South Korea, Spain, Sweden, Turkey, and the United States. The figure uses sampling (probability) weights. Observations are weighted to correct for withincountry imbalances. The graph for the average confidence uses data weighted to correct for differences in sample size but not for population size.

period 1994-2019, based on survey waves 3-7 of the WVS. The solid line captures the average confidence in the UN among respondents in the seventeen countries for which this question was asked in all five waves. It suggests that the perceived legitimacy of the UN among citizens in this diverse group of countries has declined slightly over time. While 56 percent of all respondents had a great deal or quite a lot of confidence in the $\mathrm{UN}$ at the beginning of the observation period, that figure was 45 percent at the end of the period. However, the over-time trend is quite sensitive to the countries included in the sample. Among the seventeen countries included (simply because they are available) are several that experienced very dramatic drops over this period, such as Belarus (from 71 to 50 percent), Estonia (from 70 to 52), Mexico (from 51 to 38), Peru (from 52 to 34), and Russia (from 61 to 27). It is also revealing to compare the figures for the UN to the average confidence in the national government 
in these seventeen countries, which was consistently lower throughout the observation period (not shown). Citizens thus appear to perceive the $\mathrm{UN}$ as more legitimate than their respective national governments.

Disaggregating confidence in the UN by country reveals interesting variation. Figure 11.1 shows the extent to which citizens in four specific countries have had a great deal or quite a lot of confidence in the UN over this period. These countries consist of two major powers with permanent seats on the UNSC (Russia and the USA) and two regional powers without permanent seats on the UNSC (Germany and Japan), both of whom have actively demanded reform of the UNSC. Comparing the start and end points of the observation period shows that confidence in the UN over these two decades has increased somewhat in Germany, remained stable in Japan, decreased slightly in the USA, and decreased significantly in Russia. This pattern offers limited support for the expectation that regional powers without a prominent voice in existing hierarchical IOs are generally dissatisfied with those organizations, while incumbent powers remain committed to their organizations of dominance. $^{43}$

Shifting to the EU, Figure 11.2 shows the extent to which citizens tend to trust this regional IO over the time period 2003 to 2019, based on Eurobarometer data. The solid line captures the average level of trust in the EU in all member states. It indicates that trust in the EU has varied somewhat over time, but is almost the same at the start and the end of the observation period. The same pattern exists over an even longer time period (1973-2019) if we rely on support for membership as an alternative measure of legitimacy beliefs (not shown). Figure 11.2 shows that trust in the EU rose from an average of 52 percent in 2003 to 61 percent in 2007. It then declined during the financial crisis to a level of 34 percent before it turned upward again from 2013, reaching 49 percent in 2019. There is no evidence of a persistent downward trajectory indicative of a growing legitimacy deficit, as suggested by accounts emphasizing changing governance norms and domestic backlash to globalization. Yet, if observers diagnosed the legitimacy of the EU based on the trend during the recent financial crisis, the conclusion may understandably have been negative. The stability of public opinion toward the EU is one of the principal conclusions from the voluminous literature on this topic. ${ }^{44}$ As in the case of the $\mathrm{UN}$, citizens in $\mathrm{EU}$ member states on average tend to have less trust in their national governments than in the IO (not shown).

43 See also Tallberg and Verhaegen 2020.

44 Hooghe and Marks 2005; Hobolt and de Vries 2016. 


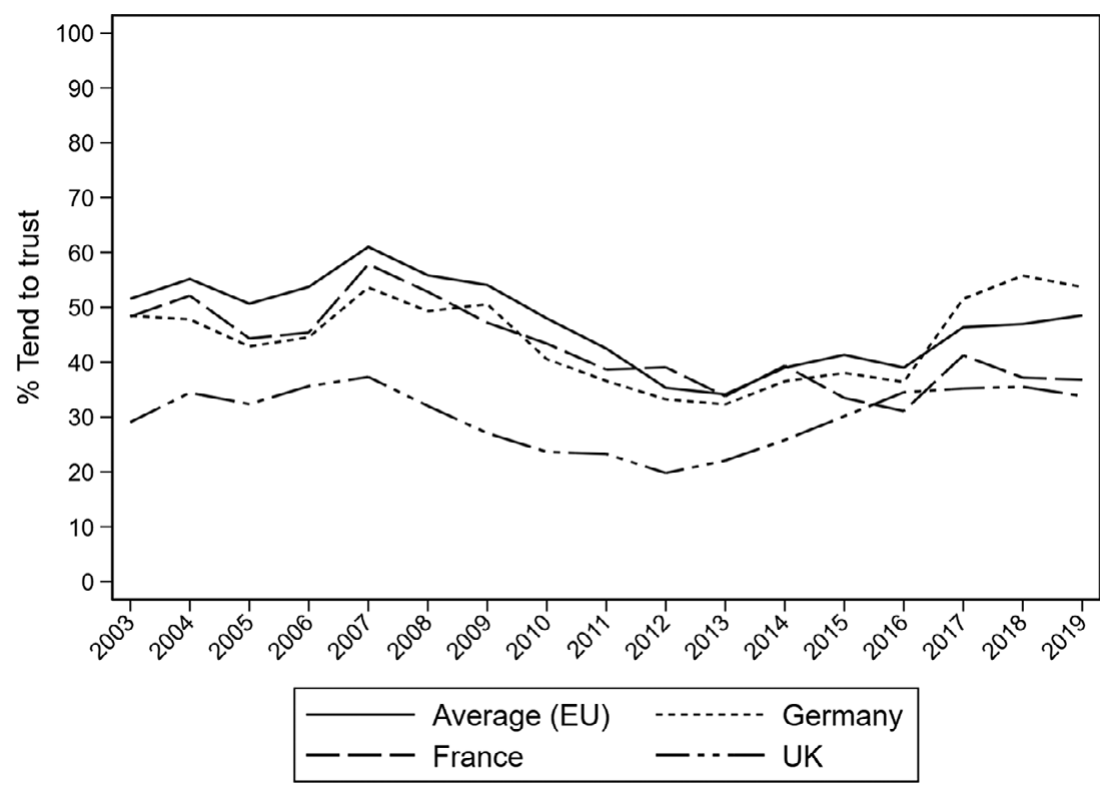

Figure 11.2 Trust in the EU, 2003-2019.

Note: Author's presentation based on data from the Eurobarometer no. 59-91 (2003-spring 2019). The average confidence in the EU is calculated based on public opinion in all member states of the IO at any given point in time. The figure uses sampling (probability) weights. The data for France, Germany, and the UK are weighted using national weights, using the special weights for a unified UK (up until the fall of 2018, after which there is no separate sample for Northern Ireland) and Germany, and the standard national weight for France. The data for the average confidence among EU citizens use the appropriate population weights (EU factor).

Figure 11.2 also disaggregates the group of member states to explore potential variation among the EU's major powers - France, Germany, and the UK. It shows that trust in the EU in France and Germany has largely followed the same trajectory over time and stayed close to the EU average, with the exception of the last five years of the observation period when French public opinion turned more negative and German public opinion more positive than the EU average. As could be expected, trust in the EU has been considerably lower in the UK during the entire time period, highlighting the type of legitimacy challenge that brought about the vote to leave the EU in 2016.

Summing up, public opinion data on the UN and the EU lend mixed support to the expectation of a growing legitimacy deficit for traditional hierarchical IOs over the past two decades. While there has been a 
decline in legitimacy over time for the $\mathrm{UN}$, this picture is sensitive to the countries included in the analysis. In the case of the EU, legitimacy has been relatively stable over time. In addition, both IOs appear to enjoy greater legitimacy than national governments in the member states.

\section{Higher Legitimacy for New Modes of Governance?}

As a second step I explore whether new modes of global governance enjoy higher levels of legitimacy than old-style hierarchical IOs. For this purpose I turn to novel findings from a recently concluded elite opinion survey. While public opinion surveys are useful for capturing broad trends in the popular legitimacy of select IOs they leave out newer modes of network- and market-based global governance. Part of the reason may be the suspicion than citizens at large are less informed about these newer types of governance. Surveying elite opinion allows us to move past this limitation since political and societal elites presumably are more aware of new modes of global governance. In addition, surveying elites has the advantage of tapping the legitimacy perceptions of the actors involved in the design of global institutions, as well as the actual global governing.

For data I rely on the LegGov Elite Survey conducted in the period 2017-2019. ${ }^{45}$ This survey conceptualized elites as people holding leading positions in key organizations in society that strive to be politically influential. The survey covered 860 elite respondents in six elite sectors: partisan-political, bureaucratic, civil society, media, research, and business. The survey targeted elites in six countries - Brazil, Germany, the Philippines, Russia, South Africa, and the USA - comprising both incumbent and rising powers. In addition, it surveyed elites in the same elite sectors at the global level (e.g., staff of IOs, international nongovernmental organizations (NGOs), and multinational corporations). The survey covered elite opinions on twelve global governance institutions that vary in terms of organizational type - IOs, TGNs, THIs, and TPAs - and governance field: economic governance, sustainable development governance, and security and human rights governance. ${ }^{46}$ This allows for a comparison between traditional IOs and new forms of governance in each of the three governance fields.

Specifically, the survey asked elites about their confidence in the following hierarchical IOs: the UN, the IMF, the ICC, the World

45 For more information on survey and sample design, see Verhaegen et al. 2019.

${ }^{46}$ In addition the survey covered eight regional institutions. 


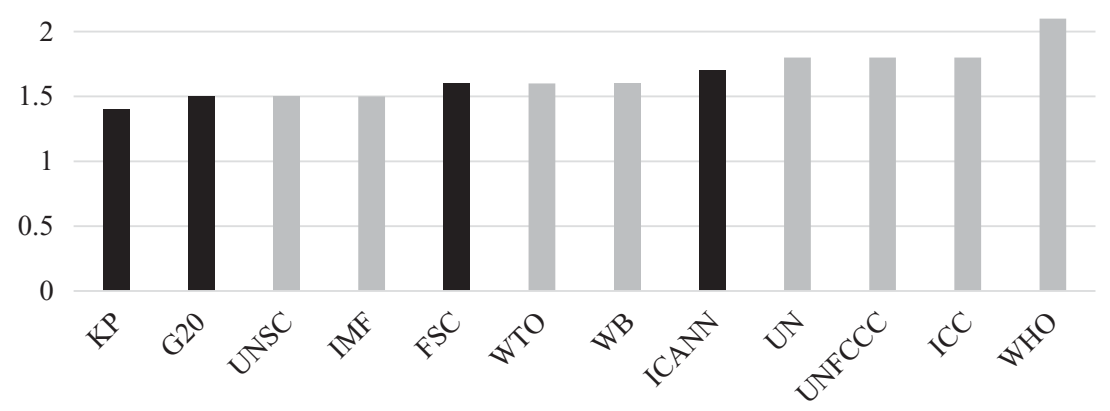

Figure 11.3 Elite confidence in IOs and new forms of governance. Source: LegGov Elite Survey

Note: Gray bars indicate IOs and black bars non-IOs. Scale ranges from "a great deal of confidence" (3) to "quite a lot of confidence" (2), "not very much confidence" (1), and "no confidence at all" (0). $\mathrm{N}_{\text {Total }}=860 ; \mathrm{N}_{\text {Brazil }}=124$; $\mathrm{N}_{\text {Germany }}=123 ; \mathrm{N}_{\text {Philippines }}=122 ; \mathrm{N}_{\text {Russia }}=108 ; \mathrm{N}_{\text {South Africa }}=123 ; \mathrm{N}_{U S A}=122$; $\mathrm{N}_{\text {Global }}=138$.

Bank, the WHO, the WTO, the UNFCCC, and the UNSC. ${ }^{47}$ Additionally, it asked respondents about their confidence in four global institutions representative of new modes of governance: the G20, the Internet Corporation for Assigned Names and Numbers (ICANN), the Forest Stewardship Council (FSC), and the Kimberley Process (KP). The G20 is a transgovernmental network founded in 2008 that brings together the leaders of the twenty most powerful countries in the world. ICANN is a transnational private arrangement established in 1998 to regulate critical aspects of global Internet infrastructure. The FSC, too, is transnational private arrangement, founded in 1993 and well known for its sustainability certification of timber products. The KP, finally, is a transnational hybrid institution initiated in 2000, which brings together public and private actors in a cooperative process to stop trade in "conflict diamonds."

Figure 11.3 shows the average level of elite confidence in each of the twelve institutions, divided into old and new types of global governance. It reveals that elites tend to have slightly more confidence in traditional hierarchical IOs than in institutions representing new modes of global

47 The UNSC was included next to the UN in order to assess if opinions toward this UN body differed from general opinions toward the UN as a whole, given the institutionalized power disparities and absent reforms of the UNSC. 


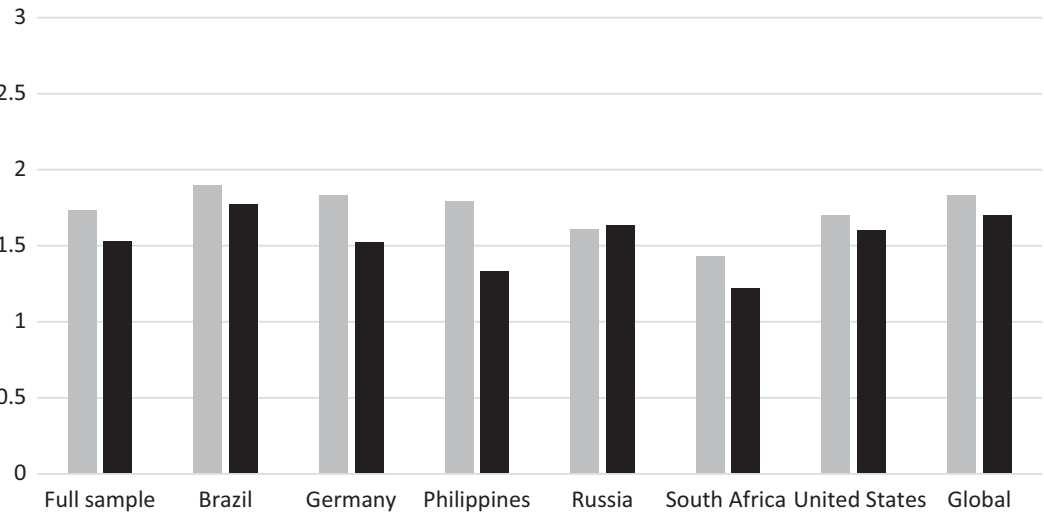

Figure 11.4 Elite confidence by country: IOs versus new forms of governance.

Source: LegGov Elite Survey

Note: Gray bars indicate IOs and black bars non-IOs. Scale ranges from "a great deal of confidence" (3) to "quite a lot of confidence" (2), "not very much confidence" (1), and "no confidence at all" (0). $\mathrm{N}_{\text {Total }}=860 ; \mathrm{N}_{\text {Brazil }}=124$; $\mathrm{N}_{\text {Germany }}=123 ; \mathrm{N}_{\text {Philippines }}=122 ; \mathrm{N}_{\text {Russia }}=108 ; \mathrm{N}_{\text {South Africa }}=123$; $\mathrm{N}_{\text {USA }}=122 ; \mathrm{N}_{\text {Global }}=138$.

governance. The WHO is accorded the highest confidence among elites by some margin, followed by the ICC, the UNFCCC, and the UN at about the same level. The middle of the field consists of the two traditional economic IOs - the World Bank and the WTO - as well as two non-IOs with relatively high levels of confidence: ICANN and the FSC. Elites have least confidence in the IMF, the UNSC, the G20, and the $\mathrm{KP}$. It cannot be excluded that another and richer selection of non-IO institutions would have yielded higher levels of confidence for this category. Yet, at a minimum, this pattern questions the idea that newer modes of global governance enjoy greater legitimacy than traditional hierarchical IOs, which would explain a shift toward TGNs, THIs, and TPAs in global governance.

Figure 11.4 disaggregates elite confidence in IOs and non-IOs by country. It shows that elites in different countries and at the global level to a large extent agree in their assessments of the legitimacy of global governance institutions. With one exception, elites in all geographical samples have more confidence in traditional hierarchical IOs than in new institutional forms of global governance. The exception is Russia, where elites have as much confidence in non-IOs as they have in IOs. Yet, across the full sample, the difference between IOs and non-IOs is statistically significant. 


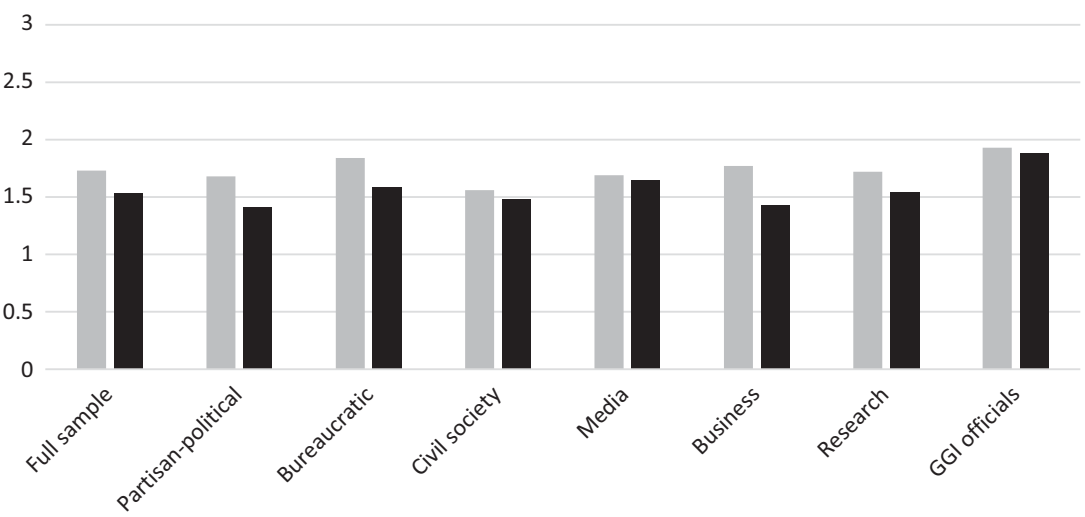

Figure 11.5 Elite confidence by sector: IOs versus new forms of governance.

Source: LegGov Elite Survey

Note: Gray bars indicate IOs and black bars non-IOs. Scale ranges from "a great deal of confidence" (3) to "quite a lot of confidence" (2), "not very much confidence" (1), and "no confidence at all" (0). $\mathrm{N}_{\text {Total }}=860 ; \mathrm{N}_{\text {Brazil }}=124$; $\mathrm{N}_{\text {Germany }}=123 ; \mathrm{N}_{\text {Philippines }}=122 ; \mathrm{N}_{\text {Russia }}=108 ; \mathrm{N}_{\text {South Africa }}=123$; $\mathrm{N}_{\text {USA }}=122 ; \mathrm{N}_{\text {Global }}=138$.

Neither is the Russian case indicative of a more general pattern of relatively higher confidence in new forms of governance among rising powers compared to the incumbent powers of the liberal international order. Excluding Russia, the differential between IOs and non-IOs is lowest among US elites and highest among Philippine elites.

Figure 11.5 disaggregates confidence in IOs and non-IOs by elite sector. It shows that elites in all sectors on average have more confidence in IOs than in institutions representing new modes of governance. The differential is largest for bureaucratic and business elites and smallest for media and civil society elites as well as elites working for global governance institutions.

To sum up, elite opinion data do not support the expectation that new modes of global governance enjoy higher levels of legitimacy than oldstyle hierarchical IOs. In fact the reverse appears to hold true for the twelve institutions examined here: elites tend to have more confidence in IOs than in non-IOs.

\section{What Explains the Resilient Legitimacy of Old Modes of Governance?}

While geopolitical shifts, new governance norms, and domestic backlash to globalization would lead us to expect declining legitimacy for 
traditional hierarchical IOs, this does not appear to be the dominant empirical pattern. What can explain this disjuncture between established expectations and empirical realities? Why is the legitimacy of old-style IOs holding up fairly well, even among citizens and elites in rising powers, while new-style institutions confront problems in winning the hearts and minds of audiences? In this section I suggest three complementary explanations for this puzzle, focused on (1) institutional reforms to traditional IOs, (2) limitations of new modes of global governance, and (3) audiences' use of heuristics when forming legitimacy beliefs.

\section{Institutional Reforms to Traditional IOs}

The first explanation suggests that traditional IOs have adapted to structural changes in world politics and thereby managed to maintain legitimacy among audiences. Rather than remaining passive in the face of geopolitical shifts, new governance norms, and domestic backlash, IOs have undertaken reforms aimed at addressing these challenges. What we are observing in terms of sustained legitimacy is the fruit of those labors.

This explanation builds on the premise that audiences care about institutional form in global governance and reward IOs that meet standards which audiences value. Recent research offers some support for this assumption. For instance, survey experiments demonstrate that citizens award IOs with greater legitimacy when these organizations are inclusive, transparent, fair, and effective, while they punish IOs that are characterized by the opposite. ${ }^{48}$ Similarly, a recent study shows that elites are more likely to consider an IO to be legitimate when they perceive its processes and outcomes as democratic, fair, and effective. ${ }^{49}$ It is therefore plausible to imagine that audiences have responded positively to the string of institutional reforms that IOs have undertaken since the end of the Cold War. Since elites are likely more aware than citizens about such institutional reforms, we can expect this explanation to be more relevant for elite compared to citizen perceptions of IO legitimacy.

In terms of responding to geopolitical shifts, IOs have in several cases sought to accommodate demands from rising powers for greater influence, representation, and recognition. ${ }^{50}$ The IMF has adjusted its voting shares to better reflect the relative economic weight of member countries, answering to demands from China especially, but also from other BRICS countries. In the WTO the core negotiating group (the Quad) has been

48 Bernauer and Gampfer 2013; Anderson et al. 2019; Bernauer et al. 2020; Dellmuth et al. 2019.

49 Verhaegen et al. 2021. $\quad{ }^{50}$ Zangl et al. 2016; Lipscy 2017; Kruck and Zangl 2020. 
extended from the USA, the EU, Japan, and Canada to also include Brazil and India, following intense pressure. All major Western powers except the USA and Japan have joined the Asian Infrastructure Investment Bank as a complement to the Asian Development Bank and the World Bank. The UNFCCC continues to take decisions through consensus and to structure obligations such that developing countries shoulder a smaller burden. The notorious exception to this pattern is the UNSC, although it should be recalled that this body already grants special status to two rising powers (China and Russia) and denies this privilege to prominent incumbent powers of the liberal international order (Germany and Japan).

The responses of traditional IOs to changing governance norms are even more far-reaching. Over the past two decades old-style IOs have been refitted for new procedural standards, including transparency, participation, and accountability. These reforms have in many cases been explicitly driven by a desire to legitimize IOs in light of new governance norms and growing societal contestation. ${ }^{51}$ IOs have seriously expanded the institutional opportunities for civil society actors to participate in policy-making. ${ }^{52}$ Many IOs have also adopted public information policies that expand transparency and instituted novel accountability procedures. ${ }^{53}$ In addition, a growing number of IOs have sought to strengthen democratic representation through the creation of international parliamentary assemblies. ${ }^{54}$

At this point in time it is more difficult to identify corresponding reforms aimed at defusing the consequences for IOs of domestic backlash to globalization. In many respects the populist backlash targets the very raison d'être of authoritative IOs, making it more difficult to respond to this type of challenge. However, there is an important nuance to consider between left-wing and right-wing populist critique of IOs. While leftwing populists typically accept the need for IOs but criticize their distributive consequences, right-wing populists reject IO authority in principle. ${ }^{55}$ In this perspective, efforts by the IMF in recent years to acknowledge its historical mistakes and reorient its policies toward a stronger emphasis on inequality reduction could potentially be interpreted as a strategy to maintain legitimacy.

\section{Limitations of New Modes of Global Governance}

The second explanation suggests that the limitations of new modes of global governance can help to account for the relatively higher legitimacy

\footnotetext{
51 Steffek et al. 2008; Zürn 2018; Dingwerth et al. 2019; Tallberg and Zürn 2019.

52 Tallberg et al. 2013. ${ }_{53}$ Grigorescu 2007, 2010. ${ }_{54}^{5}$ Rocabert et al. 2019.

55 Hooghe et al. 2019.
} 
of traditional IOs compared to TGNs, THIs, and TPAs. We may conceive of these limitations in terms of procedure and performance, both of which are qualities of global governance institutions that audiences care about. ${ }^{56}$ On the procedural side, new modes of global governance may sometimes be worse positioned than traditional IOs in meeting standards embraced in society. While new-style institutions often trumpet their strengths relative to IOs in terms of integrating expertise, promoting efficiency, and expanding stakeholder participation, their organizational form simultaneously comes at a cost. The shift from hierarchy to network as the organizing principle makes it more difficult to ensure proper accountability and equal representation. ${ }^{57}$ Internal accountability is a well-known challenge for institutions that operate without designated (member state) principals, leading to efforts at securing accountability externally vis-à-vis a more diffuse cast of stakeholders. ${ }^{58}$ Similarly, the greater inclusion of private actors in governing automatically raises questions about the democratic status of these actors and the principles of representation. ${ }^{59}$

On the performance side, new modes of global governance may face particular challenges when taking on governance gaps left behind by traditional IOs. According to one proposition, new modes of global governance have grown out of difficulties for hierarchical IOs in tackling more wicked policy problems. ${ }^{60}$ While the traditional IOs effectively picked off the low-hanging fruit in the second half of the twentieth century they have since encountered more difficult problems, which they have been unable to settle with the same success. Born out of efforts to address these problems new modes of global governance face a more difficult task. On the one hand, the problems they take on may be less amenable to simple solutions. On the other hand, their looser organizational form may partly reflect an unwillingness among states to invest in institutional solutions that are more politically costly.

\section{The Role of Heuristics}

A third reason why the legitimacy of conventional IOs may hold up well relative to that of new forms of governance is the role of heuristics in opinion formation. Public opinion scholars have long argued that most citizens have low-quality opinions and therefore rely on cognitive heuristics to help them form attitudes toward political institutions. ${ }^{61}$

56 Bernauer et al. 2020; Dellmuth et al. 2019. $\quad 57$ Bernstein 2011; Scholte 2011.

58 Grant and Keohane 2005. ${ }^{59}$ Bexell et al. 2010. ${ }^{60}$ Introduction.

61 Mondak 1993; Chong and Druckman 2007. 
A heuristic is a cognitive problem-solving strategy (or mental shortcut) that allows an individual to ignore some information with the goal of making a decision more efficiently. ${ }^{62}$ Recent research indicates that such dynamics are also at play in the formation of legitimacy beliefs toward global institutions and would benefit well-known and hierarchical IOs over newer and more fluid forms of governance. Specifically, these studies point to the use of two types of heuristics: recognition and representativeness.

When individuals make use of the recognition heuristic they assume that objects they recognize are of greater value simply because they recall them. A recent study shows this type of heuristic to influence how NGOs rate the legitimacy of election-monitoring organizations. ${ }^{63}$ When NGOs were asked to rate the legitimacy of hypothetical organizations there was some evidence that NGOs based such assessments on the institutional qualities of organizations in terms of procedure and performance. However, when NGOs instead were asked to rate the legitimacy of real-world organizations they decisively favored the EU and the $\mathrm{UN}$ over the Carter Center, a private election-monitoring organization less familiar to respondents but typically regarded as one of the best-performing. If this dynamic is at play among citizens and elites in general it can help to explain why traditional and well-known IOs continue to score high in terms of legitimacy, while newer and less well-known TGNs, THIs, and TPAs enjoy less legitimacy.

When individuals make use of the representativeness heuristic they form opinions about an object based on its resemblance to a model they know. Recently, research on legitimacy in global governance has discovered an empirical regularity that likely reflects widespread use of this heuristic. A large number of studies have established that citizen beliefs in the legitimacy of national political institutions and IOs are highly linked. ${ }^{64}$ The more citizens perceive national governments, legislatures, and courts as legitimate, the more likely they are to regard international executives, parliamentary assemblies, and courts as legitimate. This finding is consistent across IOs, time, alternative measures of legitimacy, and surveys. Moreover, it is substantively important: the perceived legitimacy of domestic political institutions is usually the strongest predictor of an IO's legitimacy. The logic behind this finding suggests that citizens use their attitudes toward the national political institutions they know relatively better when forming opinions about the IOs they know relatively

62 Simon 1957; Kahneman et al. 1982. $\quad{ }^{63}$ Nielson et al. 2019.

${ }^{64}$ E.g., Harteveld et al. 2013; Voeten 2013; Armingeon and Ceka 2014; Schlipphak 2015; Dellmuth and Tallberg 2018. 
less well. The implication is that hierarchical IOs, which resemble national governments more closely than new forms of global governance, also are more likely to be rated as legitimate by citizens approving of domestic political institutions.

\section{Conclusion}

Following on from earlier chapters describing the transformation of global governance, this chapter has examined one of its potential sources: the legitimacy of old and new forms of global governance. Could the gradual shift toward new-style institutions be driven by concerns with the legitimacy of old-style IOs? I have explored this question in three steps and end in a negative verdict.

While several accounts of the changing architecture of global governance assign a causal role to legitimacy concerns there is no strong pool of evidence in public and elite opinion for the expected patterns. Trends in the perceived legitimacy of traditional IOs show a mixed picture. In addition, there is no evidence to support the notion that new modes of global governance would enjoy greater legitimacy than hierarchical IOs, even among the elites that negotiate the institutions of global governance.

My explanation for this disjuncture between expectations and empirics is threefold. Traditional IOs have engaged in reforms that may have partly diffused legitimacy concerns. New modes of global governance face their own challenges in meeting societal expectations on procedure and performance. Citizens and elites make use of heuristics when forming legitimacy beliefs - to the advantage of well-known and hierarchical IOs over less familiar and more diffuse forms of new global governance.

In all, this chapter gives us reason to be skeptical of legitimacy as a factor driving changes in the dominant modes of global governance. While accounts emphasizing geopolitical shifts, changing governance norms, and domestic backlash to globalization all invoke legitimacy concerns as a factor in the transformation of global governance, this chapter offers limited support for this expectation. There is little to suggest that low legitimacy for old modes of governance has been a push factor, nor that high legitimacy for new modes of governance has been a pull factor, in this transformation. Instead, the greater legitimacy still accorded to old modes of governance compared to new modes of governance suggests that other drivers, distinct from legitimacy, are the principal source of the new global governance architecture. 


\section{References}

Alter, Karen J., James Thuo Gathii, and Laurence Helfer. 2016. Backlash against International Courts in West, East, and Southern Africa: Causes and Consequences. European fournal of International Law 27: 293-328.

Anderson, Brilé, Thomas Bernauer, and Aya Kachi. 2019. Does International Pooling of Authority Affect the Perceived Legitimacy of Global Governance? Review of International Organization 14: 661-683.

Andonova, Liliana B. 2019. Governance Entrepreneurs: International Organizations and the Rise of Global Public-Private Partnerships. Cambridge: Cambridge University Press.

Armingeon, Klaus and Besir Ceka. 2014. The Loss of Trust in the European Union during the Great Recession since 2007: The Role of Heuristics from the National Political System. European Union Politics 15 (1): 82-107.

Avant, Deborah D., Martha Finnemore, and Susan K. Sell, eds. 2010. Who Governs the Globe? New York: Cambridge University Press.

Baccini, Leonardo and Andreas Dür. 2014. Investment Discrimination and the Proliferation of Preferential Trade Agreements. Fournal of Conflict Resolution 59 (4): 617-644.

Bäckstrand, Karin. 2008. Accountability of Networked Climate Governance: The Rise of Transnational Climate Partnerships. Global Environmental Politics 8 (3): 74-86.

Barnett, Michael and Martha Finnemore. 2004. Rules for the World: International Organizations in Global Politics. Ithaca, NY: Cornell University Press.

Benner, Thorsten, Wolfgang H. Reinicke, and Jan Martin Witte. 2004. Multisectoral Networks in Global Governance: Towards a Pluralistic System of Accountability. Government and Opposition 39 (2): 191-210.

Bernauer, Thomas and Robert Gampfer. 2013. Effects of Civil Society Involvement on Popular Legitimacy of Global Environmental Governance. Global Environmental Change 23 (2): 439-449.

Bernauer, Thomas, Steffen Mohrenberg, and Vally Koubi. 2020. Do Citizens Evaluate International Cooperation Based on Information about Procedural and Outcome Quality? Review of International Organizations 15: 505-529.

Bernstein, Steven. 2011. Legitimacy in Intergovernmental and Non-State Global Governance. Review of International Political Economy 18 (1):17-51.

Bexell, Magdalena, Jonas Tallberg, and Anders Uhlin. 2010. Democracy in Global Governance: The Promises and Pitfalls of Transnational Actors. Global Governance 16: 81-101.

Binder, Martin and Monica Heupel. 2015. The Legitimacy of the UN Security Council: Evidence from Recent General Assembly Debates. International Studies Quarterly 59 (2): 238-250.

Bodansky, Daniel M. 1999. The Legitimacy of International Governance: A Coming Challenge for International Environmental Law? American fournal of International Law 93 (3): 596-624.

Buchanan, Allen and Robert O. Keohane. 2006. The Legitimacy of Global Governance Institutions. Ethics $\mathcal{E}$ Global Politics 20 (4): 405-437. 
Chong, Dennis and James N. Druckman. 2007. Framing Theory. Annual Review of Political Science 10 (1): 103-126.

Dahl, Robert A. 1999. Can International Organizations Be Democratic? A Skeptic's View. In Democracy's Edges, edited by Ian Shapiro and Casiano Hacker-Cordon, 19-36. Cambridge: Cambridge University Press.

Dellmuth, Lisa M. 2018. Individual Sources of Legitimacy Beliefs: Theory and Data. In Legitimacy in Global Governance: Sources, Processes, and Consequences, edited by Jonas Tallberg, Karin Bäckstrand, and Jan Aart Scholte, 37-55. Oxford: Oxford University Press.

Dellmuth, Lisa M., Jan Aart Scholte, and Jonas Tallberg. 2019. Institutional Sources of Legitimacy in Global Governance: Unpacking Procedure and Performance. Review of International Studies 45 (4): 627-646.

Dellmuth, Lisa M. and Jonas Tallberg. 2015. The Social Legitimacy of International Organisations: Interest Representation, Institutional Performance, and Confidence Extrapolation in the United Nations. Review of International Studies 41 (3): 451-475.

2018. Why National and International Legitimacy Beliefs Are Linked: Social Trust as an Antecedent Factor. Review of International Organizations 15: 311-337.

Dingwerth, Klaus, Antonia Witt, Ina Lehmann, Ellen Reichel, and Tobias Weise (2019) International Organizations under Pressure: Legitimating Global Governance in Challenging Times. Oxford: Oxford University Press.

Easton, David. 1975. A Re-assessment of the Concept of Political Support. British Fournal of Political Science 5 (4): 435-457.

Fukuyama, Francis. 1992. The End of History and the Last Man. New York: Free Press.

Gleditsch, Kristian Skrede and Michael D. Ward. 2008. Diffusion and the International Context of Democratization. International Organization 60 (4): 911-933.

Grant, Ruth W. and Robert O. Keohane. 2005. Accountability and Abuses of Power in World Politics. American Political Science Review 99 (1): 29-43.

Grigorescu, Alexandru. 2007. Transparency of Intergovernmental Organizations: The Roles of Member States, International Bureaucracies and Nongovernmental Organizations. International Studies Quarterly 51 (3): 625-648.

2010. The Spread of Bureaucratic Oversight Mechanisms across Intergovernmental Organization. International Studies Quarterly 54 (3): 871-886.

Harteveld, Eelco, Tom van der Meer, and Catherine E. de Vries. 2013. In Europe We Trust? Exploring Three Logics of Trust in the European Union. European Union Politics 14 (4): 542-565.

Held, David. 1995. Democracy and the Global Order: From the Modern State to Cosmopolitical Governance. Cambridge: Polity Press.

Hobolt, Sara B. and Catherine E. de Vries. 2016. Public Support for European Integration. Annual Review of Political Science 19: 413-432.

Hooghe, Liesbet and Gary Marks. 2005. Calculation, Community and Cues: Public Opinion on European Integration. European Union Politics 6 (4): 419-443. 
2009. A Postfunctionalist Theory of European Integration: From Permissive Consensus to Constraining Dissensus. British Fournal of Political Science 39 (1): $1-23$.

Hooghe, Liesbet, Gary Marks, Tobias Lenz, Jeanine Bezuijen, Besir Ceka, and Svet Derderyan. 2017. Measuring International Authority: A Postfunctionalist Theory of Governance. Oxford: Oxford University Press.

Hooghe, Liesbet, Tobias Lenz, and Gary Marks. 2019. The Delegitimation of International Governance. Review of International Organizations 14: 731-743.

Hurd, Ian. 2007. After Anarchy: Legitimacy and Power in the United Nations Security Council. Princeton: Princeton University Press.

Ikenberry, G. John. 2018. The End of Liberal International Order? International Affairs 94 (1): 7-23.

Inglehart, Ronald and Christian Welzel. 2005. Modernization, Cultural Change, and Democracy. Cambridge: Cambridge University Press.

Inglehart, Ronald and Pippa Norris. 2017. Trump and Populist-Authoritarian Parties: The Silent Revolution in Reverse. Perspectives on Politics 15 (2), 443-454.

Johnson, Tana. 2011. Guilt by Association: The Link between States' Influence and the Legitimacy of Intergovernmental Organizations. Review of International Organizations 6: 57-84.

Kahler, Miles, ed. 2009. Networked Politics: Agency, Power, and Governance. Ithaca, NY: Cornell University Press.

Kahneman, Daniel, Paul Slovic, and Amos Tversky, eds. 1982. Fudgment under Uncertainty: Heuristics and Biases. Cambridge: Cambridge University Press.

Kelley, Judith G. and Beth A. Simmons. 2015. Politics by Numbers: Indicators as Social Pressure in International Relations. American fournal of Political Science 59 (1): 55-70.

Kruck, Andreas and Bernhard Zangl. 2020. Bringing Negotiations Back In: Instiutional Adaptations to Global Power Shifts. Global Policy 11 (3): 5-16.

Lindberg, Leon N. and Stuart A. Scheingold. 1970. Europe's Would-Be Polity: Patterns of Change in the European Community. Englewood Cliffs, NJ: Prentice Hall.

Lipscy, Philip Y. 2017. Renegotiating the World Order: Institutional Change in International Relations. Cambridge: Cambridge University Press.

Lord, Christopher and David Beetham. 2001. Legitimizing the EU: Is There a "Post-Parliamentary" Basis for Its Legitimation? fournal of Common Market Studies 39 (3): 443-462.

Mondak, Jeffrey J. 1993. Public Opinion and Heuristic Processing of Source Cues. Political Behavior 15 (2): 167-192.

Moravcsik, Andrew. 1997. Taking Preferences Seriously: A Liberal Theory of International Politics. International Organization 51 (4): 513-553.

Morse, Julia and Robert O. Keohane. 2014. Contested Multilateralism. Review of International Organizations 9 (4): 385-412.

Newton, Ken and Pippa Norris. 2001. Confidence in Public Institutions: Faith, Culture or Performance? In Disaffected Democracies: What's Troubling the Trilateral Countries?, edited by Susan J. Pharr and Robert D. Putnam, 52-73. Princeton: Princeton University Press. 
Nielson, Daniel L., Susan D. Hyde, and Judith Kelley. 2019. The Elusive Sources of Legitimacy Beliefs: Civil Society Views of International Election Observers. Review of International Organizations 14: 685-715.

Norris, Pippa. 2011. Democratic Deficit: Critical Citizens Revisited. Cambridge: Cambridge University Press.

O'Brien, Robert, Anne Marie Goetz, Jan A. Scholte, and Marc Williams. 2000. Contesting Global Governance: Multilateral Institutions and Global Social Movements. Cambridge: Cambridge University Press.

Risse-Kappen, Thomas. 1996. Collective Identity in a Democratic Community: The Case of NATO. In The Culture of National Security: Norms and Identity in World Politics, edited by Peter J. Katzenstein, 357-399. New York: Columbia University Press.

Rittberger, Bernhard and Philip Schroeder. 2016. The Legitimacy of Regional Institutions. In The Oxford Handbook of Comparative Regionalism, edited by Tanja Börzel and Thomas Risse, 579-599. Oxford: Oxford University Press.

Rittberger, Volker, Bernhard Zangl, and Andreas Kruck. 2012. International Organization, 2nd edition. Basingstoke: Palgrave Macmillan.

Rocabert, Jofre, Frank Schimmelfennig, Loriana Crasnic, and Thomas Winzen. 2019. The Rise of International Parliamentary Institutions: Purpose and Legitimation. Review of International Organizations 14: 607-631.

Scharpf, Fritz. 1999. Governing in Europe: Effective and Democratic? Oxford: Oxford University Press.

Schlipphak, Bernd. 2015. Measuring Attitudes toward Regional Organizations outside Europe. Review of International Organizations 10 (3):351-375.

Scholte, Jan Aart, ed. 2011. Building Global Democracy? Civil Society and Accountable Global Governance. Cambridge: Cambridge University Press.

Simon, Herbert. 1957. Social and Rational: Mathematical Essays on Rational Human Behavior in a Social Setting. New York: Wiley.

Slaughter, Anne-Marie. 2005. A New World Order. Princeton: Princeton University Press.

Steffek, Jens, Claudia Kissling, and Patrizia Nanz. Eds. 2008. Civil Society Participation in European and Global Governance: $A$ Cure for the Democratic Deficit? Basingstoke: Palgrave Macmillan.

Stephen, Matthew D. 2017. Emerging Powers and Emerging Trends in Global Governance. Global Governance 23: 483-502.

Stephen, Matthew D. and Michael Zürn, eds. 2019. Contested World Orders: Rising Powers, Non-State Actors, and the Politics of Authority beyond the Nation-State. Oxford: Oxford University Press.

Suchman, Marc C. 1995. Managing Legitimacy: Strategic and Institutional Approaches. The Academy of Management Review 20 (3):571-610.

Tallberg, Jonas, Karin Bäckstrand, and Jan Aart Scholte, eds. 2018. Legitimacy in Global Governance: Sources, Processes, and Consequences. Oxford: Oxford University Press.

Tallberg, Jonas and Michael Zürn. 2019. Legitimacy and Legitimation in International Organizations: Introduction and Framework. Review of International Organizations 14: 581-606. 
Tallberg, Jonas and Soetkin Verhaegen. 2020. The Legitimacy of International Institutions among Rising and Established Powers. Global Policy 11 (3): $115-126$.

Tallberg, Jonas, Thomas Sommerer, and Theresa Squatrito. 2016. Democratic Memberships in International Organizations: Sources of Institutional Design. Review of International Organizations 11 (1): 59-87.

Tallberg, Jonas, Thomas Sommerer, Theresa Squatrito, and Christer Jönsson. 2013. The Opening Up of International Organizations: Transnational Access in Global Governance. Cambridge: Cambridge University Press.

2014. Explaining the Transnational Design of International Organizations. International Organization 68 (4): 741-774.

Vabulas, Felicity and Duncan Snidal. 2013. Organization without Delegation: Informal Intergovernmental Organizations (IIGOs) and the Spectrum of Intergovernmental Arrangements. Review of International Organizations 8 (2): 193-220.

Verhaegen, Soetkin, Jan Aart Scholte, and Jonas Tallberg. 2019. Elite Attitudes Toward Global Governance. A Report of Summary Findings from the LegGov Elite Survey. Gothenburg and Stockholm: University of Gothenburg and Stockholm University.

2021. Explaining Elite Perceptions of Legitimacy in Global Governance. European Fournal of International Relations. https://doi.org/10.1177\% 2F1354066121994320.

Voeten, Erik. 2013. Public Opinion and the Legitimacy of International Courts. Theoretical Inquiries in Law 14 (2): 411-436.

2020. Populism and the Backlashes against International Courts. Perspectives on Politics 18 (2): 407-422.

Weber, Max. 1978 [1922]. Economy and Society. Berkeley and Los Angeles: University of California Press.

Weiss, Thomas G. and Rorden Wilkinson. 2014. Rethinking Global Governance: Complexity, Authority, Power, Change. International Studies Quarterly 58 (1): 207-215.

Zangl, Bernhard, Frederick Haussner, Andreas Kruck, and Xenia Lanzendörfer. 2016. Imperfect Adaptation: How the WTO and IMF Adjust to Shifting Power Distributions among Their Members. Review of International Organizations 11: 171-196.

Zürn, Michael. 2000. Democratic Governance beyond the Nation-State: The EU and Other International Institutions. European fournal of International Relations 6 (2): 183-221.

2018. A Theory of Global Governance: Authority, Legitimacy, and Contestation. Oxford: Oxford University Press. 